\title{
7. PROFESSOR OF ART PARADIGMS: THEORETICAL AND APPLIED APPROACHES
}

Tatiana Bularga ${ }^{11}$

\begin{abstract}
The present article describes purposes, learning content and requirements of an educational academic and postgraduate (internships for teachers) process, focused on teacher training in respect of the most subtle and valuable framework for education, the achievement of the individual potential of each pupil, qualified as a unique personality. Therefore, it is proposed a synthesis on the formative program geared towards the assimilation of the future and current teachers of artistic disciplines (music, choreography, painting) of the action and behavioral models appropriate to the domain, to the effectively organization of individualized educational process.
\end{abstract}

Key words: teacher of artistic disciplines, training program, learning content, purposes, professional competence, effectiveness of teacher's actions, innovative praxeology, renovation in artistic education, originality of thought, creativity, proactivity

\section{Introduction}

We aimed to study the activity of the educational and training of the practitioner from the viewpoint of several positions that have significant importance especially as concerns the implementation of the innovative praxeology and namely - the verification of the correlation between the variables: professionalism and pedagogical competence, artistry and continuous self-improvement. Based on these statements, we established the following praxiologic correlations:

- the degree of possession of technologies to promote an operational and qualitative actuating style by teacher-practitioner;

- the dimension of stimulating the independence of pupil/student in the efficient design and implementation of artistic actions;

- among the foreseeable risks to which we can expect in the practice of teaching-learning-assessment we could highlight as risks which remain open for the innovative praxeology implementation process, such as the operationalization of three variables with an area of consecutive deployment and which are specific to an artistic action: design-organization-achievement.

\section{Conditions under which the artistic action takes place}

The educational-training environment highlights the legal approaches necessary to conduct qualitatively the teaching-learning-training process (Curriculum, contents, methods, principles, objectives, strategies, concepts, manuals, methodological guides etc.). As for the nature of the nominated environment, it would be primarily about fostering at pupils/students the individual need for self-improvement, change and perfection. We address these

\footnotetext{
${ }^{111}$ Associate Professor PhD., „Alecu Russo” State University from Bălţi, Republic of Moldavia, email: email: tatianabularga@ rambler.ru
} 
qualities of personality not only to emphasize the preferences for a certain type of activity, but for the perfection as a way of life, as a way of being, existing and activating.

The individual environment, unlike other environments, is a rather difficult environment, closed, because in the centre of its functioning is the object/subject of education - the pupil/student with his multiple and diverse features: psychological (attention, thought, will, imagination, affection, etc.), features of personality (cognition, intelligence, attitudes, awareness, empathy, etc.); behavioural (actuating reproductive/creative, proactive/reactive, value/nonvalue cantered, open/closed, situated in success/failure etc.). Each person in contact with the cultural, educational-training environment forms a space, a personal and individual intellectual environment. The intervention of new phenomena in space or individual environment, according to the principles that a specific person is guided, according to the content of individual maps (the sequence of actuating steps performed according with the effective/ineffective principles), to the positive/negative behaviour - all this forms that unique and original style of personality.

The artistic environment integrates the educational-training environment and the individual environment, which provides the teacher and the pupil/student the chance to relate, balanced in order to contribute to an effective result. The artistic environment is a subdivision of hereditary and social environments claiming to wholeness, because it is the cornerstone of integrity. In other words, this environment, we may say, is an outer shell and also an internal incorporation in the personality structure, creating that framework, space, environment of expression and self-realization of individual potentialities. The activism of pupil/student manifested through critical thinking, integrated perception, creative, empathic and proactive imagination is a mediator factor, connecting the inner world and the outer world of the person.

All the above mentioned three environments have a theoretical and a practical significance. Thus, the pedagogical praxis cannot function without theoretical material, and vice versa, educational theory would be meaningless without basic experiments carried out on the field; theoretical knowledge acquisition by the pupil/student would be a useless storage without conscious application in practice; the innovative experiences would remain unused and not conceptualized, without a theoretical and methodological instrumentation because they become a route with a generalizing value significance and continue progressing of the formative praxis.

\section{Factors accompanying the artistic action}

The human action, partly the artistic action remains, as previously mentioned the link between theory and practice, which requires us to emphasize its accompanying factors from the perspective of an effective praxeology. Among the factors accompanying the artistic action we will expose the following: 
- the interventions of so-called positive factors, with facilitator input and the so-called factors, with negative input. The fact is that from case to case, each of these factors can influence both positively and negatively: the targeting process with elements of the artistic empathy of pupil/student; transposition into another role, including in artistic roles; superposition of own feelings with the feelings of others; the intimate opening through the senses, artistic ideas etc.

- AA effectiveness motivation expressed through reasons-inputs: imitation, practice, achievement according to the model or "maps" prescribed from the outside, rebuilding, change, dynamics, activism, freedom of decision, taking initiatives, self-management;

- motivational success, approached in terms of the principle of stimulating, organization and achievement artistic actions of pupil/student;

- reasons-values, conceptualized in the artistic proactivity and specified as follows:

a. the reason of "tacit influence" (W. G. Jordan) aiming to influencing pupil/student by the way of "being", manifesting himself as he is, hearing and understanding art, creating, performing - all these actions encouraged by the factor-reason "tacit influence";

b. the reason "lasting satisfaction" (St. R. Covey) is an overriding need related to the artistic activity. This reason gives the person resistance, strength of character to resume the repeated action;

c. the reason of artistic transfer on other areas of activity;

- artistic communication, achieved by specific means of language (eg., musical) and by other arts (intonation, poetic verbalization, mime/pantomime, rhythmic movements/dance);

- external and internal stimulation;

- real and ideal result (effect);

- evaluation and self evaluation of own behaviours and those of others;

\section{Design, organization and achievement of a practical artistic action}

Such processes are developed based on legalities of functioning of proactivity principle. The following things are highlighted:

1) the objective of artistic actions of pupils/students:

- to act proactively, ie to act with maximum will and initiative;

2) individual qualities of pupil/student, transferrable in proactive style.

a) valuing individual potentialities means targeted actuating of pupil/student to the full achievement of personal resources (consciousness, abilities/skills):

- consciousness in the artistic action has a function of change towards spiritual integration by paradigms from outside to inside, from the inside out and in personal content;

- individual skills include variables that define resources for the successful realization of artistic actions and lies in:

- presence of emotional tone;

- storage and optimal preservation of artistic information;

- effective mental processing of auditory representations; 
- flexibility of artistic thinking;

- critical attitude towards impressions suggested by art;

- practical abilities/skills - inevitable resources in the context of actions with high results. In music, for example, we specify the following reference capacities:

- differentiated and integrated perception of music;

- verbalization/comment and artistic interpretation of music content;

- improvisation/elementary music composition.

b) auto-regulation of positive actions is a variable behaviour related to the phrase cause - effect, due to the fact that any cause will stimulate an effect on the condition that this effect will be well designed/planned. In the context of the paradigm of qualitative change the person is oriented to cultivate a style of self control of convergent actions, i.e. to focus efforts on a theoretical level (analysis, comparison, judgment, awareness) and on practical level (rejection of negative influences and circumstances and acceptance/valuing the positive ones).

Thus, we will give priority to key objectives:

- to foster positive thinking;

- to start the design of artistic actions from the end, because every product of art is a finality, an actional model developed in time, worth to be followed.

c) reporting the own initiatives to the efficient ideal. The efficient person does not expect solutions of situations and problems but meets them with own initiatives and opportunities. Reporting personal initiatives to the accepted educational/cultural models, ideals imply a state of criticism and self-criticism, representing a new stage in the evolutionary process of paradigm change. In this regard, the benchmark is to opt for a qualitative action and outcome.

d) taking responsibilities. The person oriented on qualitative results usually wants is prone to come up with a skilful response(respons+ability) or, in other words, it analyzes well the level of personal resources (quantitative and qualitative indices) and sets the imprinting (moment) of adopting decisions to respond to his actions and not blame circumstances or not giving to others' personal failure. The reference objectives are:

- to choose answers according to situations;

- to create positive artistic circumstances;

- to dominate circumstances and representations, feelings, personal experiences;

- to take responsibility for verbal messages and artistic performances;

e) cultivating a proactive language. Through spoken or artistic language occurs the transmission outside of informational materials, including affective and emotional states of the internal world. The word is the main exponent of judgments, of our intentions. To foster a proactive language to educational plan means to change your mental paradigm towards yourself and others, especially when we are referring to a process mediated by artistic values. As for the persons focused on the result, personal/public achievement, the paradigm of proactive language will have the following meanings: "I will manage to perceive 
deeply the musical message", "I want to know fully the values of music", "I will bring the started musical and artistic action to the very end".

The dynamics of qualitative changes take place: through perception/interpretation:

- musical and artistic content of creation (idea, theme, character);

- form and area of exposure / execution (vocal, instrumental, dramatic tale, lyric, etc.);

- psychological load (depth of feelings, suggestive power, empathic dimension);

- the effect of organizational change (re-organization, planning, change of behavioural attitudes, tendency to success);

- independent actuation: taking experimental and self-education initiatives.

\section{Mediation of teacher}

The practitioner assumes a great formative responsibility because he evolves in the position of educator and manager of interdisciplinary process (pedagogy, psychology, philosophy, musicology and aesthetics). Teaching, educational and managerial skills of teacher are put into action according to curricular strategies, reported to the social demands submitted to education. Given the obligations and responsibilities that the practitioner assumes for the educational cause, hereafter, we will specify the main roles that a teacher praxeologyst must fulfil:

Firstly, he should be:

- observer and mediator of environmental processes (individual environment $\leftrightarrow$ artistic environment $\leftrightarrow$ instructive and educational/social environment);

- producer of cognitive and formative ideas and messages;

- coordinator of individual and group actions/situations;

- designer of actions, strategies, programs, plans (Joiţa, 2000);

- experimenter of ideas, of individual and collective hypotheses;

- information source, behavioural model, bearer of values (Joiţa, 2000);

Secondly, he should assume responsibility for:

- managerial orientation of personality;

- initiation of varieties of ideas, assumptions, projects of actionable maps;

- reasonable decision-making, drawing up and adopting maps of artistic behaviour;

- choice of content and strategies, intellectual resources according to the required effort;

- differentiated guidance with actuating operation;

- obstructing the non-value factors/components of artistic actions of pupils/students;

- renovation of organizational forms, objectives and techniques to influence education;

- providing interdisciplinary integration (pedagogy, having educational and formative function). 


\section{Pedagogical roles}

Being in contact with mediation functions of the practitioner in process, pedagogical roles need to be identified and ranked because they are related to the achievement of interactive education objectives and should focus on the following objectives:

- to create from each work of art an environment in which the pupil/student will live artistic moments as a show of soul;

- to urge pupils/students to make imaginative transfers from an art to another;

- to create opening situations through art to himself, to others;

- to stimulate ingenuity, flexibility and convergence of pupils/students in designing/organizing and conducting of artistic actions;

- to be a skilled manager not only regarding launching/submission of teaching and cognitive tasks, but also in connection with their effective implementation process;

- to organize, to structure effectively the form and content of the lesson/artistic education lesson and extracurricular lessons;

- to exemplify through own shares valuable artistic experiences;

- to urge students to generalizations and independent conclusions (Arceajnicova, 1987).

\section{Psychological roles}

We reduce these roles to the development of psychological components specific to pupil/student influenced by artistic stimuli. In this context, the teacher praxeologyst must focus his work on:

- stimulation of general and special artistic skills;

- value orientation of thinking;

- interiorization of work, hearing music itself (Gagim, 2004);

- sefl-communion after audition (Gagim, 2004);

- fostering the spirit of research;

- encouraging the spirit of observation;

- development of autonomous will;

- stimulation of cognitive curiosity and special interest for artistic activities;

- orientation towards an intrinsic motivation for art;

- high evaluation of the desire to communicate, discuss, interpret verbally works of art;

- stimulation of propensity for result "for dominance in relationships with colleagues" (Creţu, 1997);

- supporting "intense emotional experiences" (Creţu, 1997).

\section{Musicological and aesthetic roles}

This group consists of roles in the formation/development of pupils'students' value attitudes oriented to active perception of creations of art with a rich and diverse content, original in form and style. Based on these objectives, the teacher must:

- develop general faculty of listening, skill of artistic hearing of world sonorities, deciphering their significance/voice (Gagim, 2004); 
- center the intellectual and artistic universe of pupil/student on human values reflected in the content of messages of folk and written by composers music;

- engage in pupil's perceptive and sensitive background the design capabilities of conducting artistic discourse legalities as virtual and real behavioral environment;

- identify spiritually with dramaturgy by connecting individual motivation/reasons with artistic reasons;

- open artistic codes by which creators of musical works influence the listener.

From the perspective of ensuring effective interdisciplinary interference, it is necessary to highlight the roles of teacher in the following areas:

a) proactive centering, accomplished through:

- drawing up maps of perceptive, interperceptive and creative behaviour;

- management of perception way, storage/preservation, securement, distribution, awareness and application of spiritual acquisitions;

- time budget management, effective rationalization of artistic actions;

- coordination, guidance, counseling on design steps and organization/implementation of pupils'/students' actions;

b) values centering on:

- orientation towards the identification of aesthetic sense of artistic creation;

- composition and improvisation of group and individual music;

- rapid and qualitative learning of music;

- fostering a proactive language;

- promoting various interests;

- advanced artistic skills;

- evaluation and critical self- evaluation;

- efficiency transfer (G. Văideanu) of teacher from artistic environment on individual environment;

c) centering on openness to art through:

- conscious penetration into the mysteries of the artistic message and empathized perception;

- motivation oriented to self and others knowledge in aesthetic and moral behavior patterns;

- offering opportunities for integration in artistic activities both horizontally and vertically;

- fostering the habit centered on behavioral paradigm gain-gain (S. Covey) within an autonomous will;

d) centering on creativity/creation through:

- reasonable and original opinions formulation;

- independent solving problems/questions-stimuli;

- polydimensional development of artistic imagination;

- responsibility for judgments, ideas open for discussion;

- optimal choice between launched ideas related to perceived artistic matter;

- delimitation of the essential from secondary, valuable from ephemeral things;

- ensuring balance between: intuitive-logical, empirical-theoretical, emotionalrational; 
e) centering of artistic actions on elements of temporal forms:

- musical tempo conceived as phenomenon "music - location in time" made by a process of reflection:

- natural (pupil moves with a speed appropriate to the orientation of character of the time given, if other active factors are not involved, i.e. a tempo within the range of an average speed);

- slowing (pupil involves in his action field everything he sees: texts of notes, diagrams, instrument, keyboard, fingers, hand), everything he hears: oral indications, melodies, rhythms, harmonies;

- accelerating (texts of notes with a relatively low values involves imagination and sensations, perceptions of pupil, a high energy transaction, which stimulates speeding of musical tempo).

- reasons-intonations, phrases-themes, episodes-refrains,reprises- cadences, which are subject to the laws of cosmic universe (gravity, attraction, intensity, movement, rest cycles, energy, speed, temporality, symmetry, shape, spaciousness, networking, mutual influence, uniqueness, trajectory, linear/ ircular/rectilinear motion etc.);

f) centering on success represent those roles which ensures the transfer:

- from individual to public success;

- from the success-tendency to success-habit;

- from the cyclic/ situational success to the integrated/holistic success;

- from success-failure paradigm to the paradigm of success-success.

The power of influencing art of communication through musical language on/to depends on inner state of the listener/actor/performer that comes in an interactive relationship with this environment. Theory and practice of artistic pedagogy insists on having a closer relationship between musical environment and pupil/student which aims to facilitate the process of influence from. The effectiveness of artistic education in context of the influence from, largely, is dependent on the correlation of tangency points between both parts - artistic environment and the person who communicates.

If factors of artistic environment influence at the entrance equally on all subjects-listeners, then the depth and area with which factors of artistic environment influence the inner state - mood, emotional, conscious - differs from one pupil/student to another. The main efficiency factors of the formative process, beginning with the states recorded from start and reported to the effect achieved at the end of a cycle (semester, academic year) are exposed in the given experimental direction (direction II) in order to be submitted to experiments on the field.

\section{Conclusions (Obstructing factors)}

In instructional and educational practice, in his actions, the practitioner often chooses the easiest path, instead of proceeding to complex actions, supported by multiple options for an effective achievement. Within the category of such practitioners, we can distinguish some persons who allow the infiltration in the process of obstructing factors, such as: 
- to achieve the expected results, in detriment of heuristic methods, teachers limit themselves to the exercise method;

- the teacher does not assume responsibility for the investigation of the artistic process, but for the result reported to a standard behaviour;

- creative efforts are not taken into account when measuring the intellectualartistic feedback;

- the results, the products of original artistic creations, are overlooked during the assessment process;

- as a rule, details are usually subject to review and not the essence of the process;

- it is believed that art, and the phenomena related to it, are not subject to logical rules;

- critical thinking is an arbitrary attribute, insignificant in the framework of artistic effectiveness;

- in the theory and practice of artistic education/teaching there isn't a complete overview of pupil's/ student's critical thinking.

\section{External factors}

1. The theoretical researches, conclusions and methodical recommendations exposed in the form of thesis, articles, essays and other theoretic and praxeological materials are not sufficiently validated on a large scale not only in practice, but especially under laboratory conditions.

2. A good amount of the researches from the training area and artistic education are too distanced from the problems practitioner teachers are faced with. This kind of distancing creates a sort of alienation between the two areas (theoretical and practical) which, while in parallel, register a small percentage of common points.

3. The homogenization of the artistic system by developing manuals, curricula, methodical guides without alternative projects leads to the teacher's refuge in the inside of the daily activity/of the empiricism and of the regularization, and as a consequence he/she is offered few options for innovation and change.

4. Some theories are developed on the basis of the conceptualization of other sciences neighbouring with pedagogy and these are not always in harmony with its subject.

5. The existence of practitioners' specific mentality to preserve the traditional depositors/accumulations and to oppose resistance to the outside influences.

6. The educational environment is open, to a lesser extent, to external observers (society, parents, administrative bodies in charge etc.), and this implies difficulties in the detection of the real situation and intervention in an opportune occasion.

7. The appreciation of the quality of students'/pupils' activity, which also includes the result of the teacher's pedagogical investment activities, is achieved by the teacher himself/herself, and this determines a low level of the objectivity at the evaluation and self-evaluation chapter.

8. The teacher's responsibility for the school achievements/success, and, especially, for the pupils'/students' extracurricular behaviour is minimal. 


\section{Internal Factors}

1. Lack of continuity related to stating the work objectives in designing and realization of AA. Much of what is projected or planned is not fulfilled or done, and this little amount is not subject to critical examination, vertically and horizontally, in order to undertake tangible steps towards promoting of the education as a change in quality.

2. Pupils'/students'/teachers' intentions and efforts towards changes in quality, aren't often supported/stimulated by relevant, nor material, nor moral, factors.

3. Pointing out the strategies/policies of change of a small number of pupils/students with special abilities to the detriment of the entire school/academic segment constitutes an instructional and educational crime.

4. The presence of teacher-practitioner's eagerness to subscribe the results and success of his/her disciples and qualify them as advantages of his/her own success. Such a charismatic style overshadows the relationship teacherpupil/student.

5. The instructional/educational environment is monopolized, which speaks for itself that pupils/students/parents have no alternative either in their choice of school/faculty, especially in terms of rural setting, and, for the most part, given that they do not take advantage of the choice of subjects of study. To this end, it is necessary to develop a list of optional disciplines and optional extracurricular activities that the pupil/student could benefit of. Artistic training/education opportunities, in this area, are quite considerable.

6. In today's artistic education, the question/issue of testing the modernist practices is not even approached in praxeological way, along with their extensive dissemination in the instructional-educational environment (IEE).

7. The impoverished initiatives of some teachers-practitioners in promoting of an education of change are qualified by peers as challenging, disordering the process which "runs quietly and without shaking".

8. The practitioner form of self-improvement through advancement in professional degree, although it constitutes a substantial approach in the dynamics of professional competence, does not save the situation, because the written works that are submitted for evaluation, are often nothing more than some transcripts from profile sources, without being accompanied by materials/arguments from teachers' personal pedagogical practice.

\section{Bibliography}

1. Babii, V. \& Bularga, T. (2014). Succesul artistic al elevilor din perspectiva devenirii personalităţii social active. [Materialele Conferinţei ştiinţifice naţionale cu participare internaţională „Fundamente psihopedagogice ale prevenirii şi combaterii violenţei în sistemul educaţional", 10 octombrie 2014, Univ. Ped. de Stat „Ion Creangă”, Fac. Psihologie şi Psihopedagogie Specială, Catedra Psihologie, pp. 214-224]. Chişinău.

2. Babii, V. \& Bularga, T. (2015). Praxiologia inovativ-artistică. Studiu praxiologic. Iași: Artes. 
3. Babii, V. (1984). Dezvoltarea aptitudinilor creative a elevilor. Pedagogul Sovietic, 12, 30-34.

4. Babii, V. (1986). Activitatea de creaţie la ora de muzică în clasa a 4-5-a. Recomandări metodice. Bălți: Centrul de calcul din Bălţi.

5. Babii, V. (1986). Antrenarea elevilor în activităţi de creaţie. Pedagogul Sovietic, 1, 41-44.

6. Babii, V. (1987). Evaluarea la lecţia de muzică. Invăţământul Public, 11 martie, 1987.

7. Babii, V. (1987). Formarea deprinderilor de muncă independentă. Pedagogul Sovietic, 2, 50-53.

8. Babii, V. (1987). Munca de creaţie a copiilor de 6 ani (Muzica în clasa I). Pedagogul Sovietic, 12, 8-11.

9. Babii, V. (1989). Creaţia muzicală a elevilor în afara orelor de curs. Pedagogul Sovietic, 10, 50-53.

10. Babii, V. (2005). Eficienţa educaţiei muzical-artistice. Chişinău: Elana V.I.

11. Babii, V. (2015). Succesul artistic al elevului. In M. Rusu (Ed.), Etic şi estetic. Modelare personală prin artă (vol. 2, pp. 287-294). Iaşi: Ars Longa.

12. Babii, V. (30-32). Dezvoltarea aptitudinilor creatoare ale elevilor: Cîntul şi muzica în şcoală. Pedagogul Sovietic, 12, 30-32.

13. Bularga, T. (2008). Psihopedagogia interesului pentru muzică. Chișinău: Elena-V.I.

14. Crețu, C. (1997). Psihopedagogia succesului. Iași: Polirom.

15. Gagim, I. (2004). Ştiinţa şi arta educaţiei muzicale. Chişinău: ARC.

16. Joița, E. (2000). Management educațional. Iaşi: Polirom. 


\title{
8. POSITIONING ARTS IN THE CURRICULUM: POSSIBLE DISCREPANCIES AND WHAT THEY SIGNIFY
}

Mihaela Mitescu Manea ${ }^{112}$

\begin{abstract}
Discrepancies in the way arts are positioned and approached in mainstream curricula in Europe afford awareness over the great diversity of contextualized actions and the social, cultural and historical tenets informing arts' role and place in relation to school based learning and education. Diversity invites exploration and may allow a better understanding of what functions as a constraint and what as an affordance to the pedagogical reforms and epistemological repositioning almost every national system of education embarked on, in contemporary Europe. It is proposed here a critical reading of the documented approaches to arts in educational practice in contemporary Europe, framing four main false dichotomies: reason vs. emotions, theory vs. practice, general aptitudes vs. specific ones and individual competences vs. collective capacity building.
\end{abstract}

Key words: educational practices, discrepancies, arts, curriculum, false dichotomies

\section{Introduction}

Arts are a relevant part of European mainstream education, and they are included in the core curriculum of most types of schools on the continent. At least, this is what the Eurydice Report: Arts and Cultural Education at School in Europe (Eurydice, 2009) is telling us in the most comprehensive analysis of educational policies and practices in Europe, to date. The measure of, and the reasons for Arts' presence in curricula differ greatly from one system of educational practice to another. In some approaches to planning the curriculum, various artistic forms are reunited in one comprehensive learning unit called Arts, in others they produce disciplinary learning units, called after the specific artistic form (i.e. Dance and choreography, Music, Photography etc.). The learning contents pertaining to Arts are either reduced to Music and Visual Arts, or are extended to include drama, dance and choreography, crafts, new media arts, architecture etc.

\section{Discussions}

Structuring and allocating the time resources for learning arts in the curriculum also greatly vary. Whilst the image is quite homogeneous for primary education, where arts are present in the mandatory parts of the curricula in all European systems of education, in secondary education the image is not so homogeneous, the arts being moved in either the optional section in the curricula, or in the extracurricular activities offered in some schools and systems of educational practice. Everywhere in secondary education curricula, the time allocated to studying in the arts is significantly less than that allocated to sciences, language and mathematics.

\footnotetext{
112 Associate Profesor PhD., "George Enescu" National University of Arts from Iasi, Romania, email: mihaelamitescu@yahoo.com
} 
When explicit concerns address the marginalization of arts in the curriculum, chances are some educational programs and projects attempt some kind of compensatory action towards diminishing the structural deficit in the curriculum. Such is the case of programs like Creative Partnerships in England, Cultural Rucksack in Norway, Kultur Agenten in Germany, or $p[A r t] s$ in Austria (Bamford, Wimmer, 2012). Creative Partnerships, for example, is a program intending to significantly impact the long term commitment and participation of young people to school learning, by employing artists in the planning of curriculum. This program in particular aims at provoking change at the level of the school as an organization, not only at the level of students' learning, in their encounter with the arts and culture.

The Eurydice Report makes this great variety of positioning Arts education in the European curricula most visible when discussing the goals and aims of arts education. At a general level, in all European countries arts education aims at training students for understanding, knowledge and skills in the arts. Additionally and vastly contextualized, school systems may attribute to arts education merits in training students for "critical reasoning", "cultural heritage", "individual expressivity", "cultural diversity" and "creativity". Only in half of the educational systems included in the Eurydice Report, however, these formative aims associate learning in the arts with lifelong learning goals and abilities.

The discrepancies in the educational policies and practices on arts education in Europe may be easier to grasp should we consider the particularities of the historical trajectories of arts and arts education in Europe, presenting many turning points and not quite a homogenous picture for the historical recognition and prestige assigned to the various forms of artistic production and expression we know of today. Discrepancies in the way arts are positioned and approached in mainstream curricula in Europe afford awareness over the great diversity of contextualized actions and the social, cultural and historical tenets informing arts' role and place in relation to school based learning and education. Diversity invites exploration and may allow a better understanding of what constrains and what affords the pedagogical reforms and epistemological repositioning almost every national system of education embarked on, in contemporary Europe. It is proposed here a critical reading of the documented approaches to arts in educational practice in contemporary Europe, framing four main false dichotomies: reason vs. emotions, theory vs. practice, general aptitudes vs. specific ones and individual competences vs. collective capacity building.

Reason and emotions. Historically inherited from the period of Enlightenment the assumption that the functions and the purpose of intellect are significantly different from those of the human emotions has prompted a number of hypotheses concerning the various areas of human activity (implicitly, of the educational activity), and their roles and purpose in relation to various projections on human accomplishment. As a result, a great dividing gap has been envisioned between arts and sciences and between their subsequent roles in 
education, with the later dealing with knowledge, facts and objective truths, and the former with the emotions, subjectivity and self-expression. Science was credited to produce objective, depersonalized, therefore reliable knowledge, whereas arts performs a compensating role by allowing for an introspective filtering of the world; sciences were regarded as truly useful, whereas arts were granted merely a complementary role in education (Robinson, 2011). In the modern world the authority over establishing what constitutes knowledge worthy of attention is unalienable and is attributed solely to an objectivist approach to understanding, teaching and learning.

A discussion of arts and sciences departing precisely from considering the point of their absolute dichotomy, as modern age proposed for education, is particularly interesting as it affords pedagogical explorations beyond the confines of complementarities of their functions in the curriculum. Sciences are deemed to cover a vast spectrum of knowledge, aiming to explain how the world works in itself; sciences are concerned with all aspects of life from nature to extra-terrestrial space, from human personality to social systems. Arts, on the other hand, are concerned with describing and expressing qualities of experiences; they cover a vast spectrum of practices, styles and traditions, historical and cultural (Robinson, 2011). Thus understood, arts and sciences fulfil complementing roles in education, providing opportunities and specific tools and means for structuring learners' knowledge about themselves and the world.

With all the advantages it affords educational practice in terms of planning and organizing a seemingly well rounded curriculum, made of well-defined and properly interconnected learning units, each responding to individualized content standards, hardly ever overlapping and allowing for a maximized efficiency in distributing pedagogical resources towards accountable educational ends, complementarities also allows for a different prioritization of the educational roles arts and sciences play in the curriculum, with the balance of pedagogical resources attributed favouring either, or. As such, it follows that over-emphasizing one in the detriment of the other is also possible, running at the risk of breaking the harmony of arts and sciences in the same, holistic educational vision.

This separation of roles for arts and sciences, albeit vividly disputed by the psychological and neuro-physiological research over the past decades (see Gardener, 1993; Goleman, 1996), is maintained in many approaches to curriculum planning today. The time may have come, though, along with the limits of an approach to curriculum building on the complementarities of functions for arts and sciences, also to carefully consider the similarities of knowledge production processes in both arts and sciences, as Robinson (2011) warns: they both include objective and subjective elements; both rely on knowledge, emotions, intuition and non-rational elements; both are driven by personal investment and motivation and both are highly creative (Robinson, 2011, p.229). 
Forming a deep understanding of what complementarities of roles and positions in the curriculum actually entails for both the effects on learning and for the actual learning experience, and deeply understanding what may constitute a common ground for both arts and sciences in terms of knowledge production seem advisable enterprises. Even more so when reformist discourses on education almost everywhere claim to invest a very big interest in identifying approaches to learning and pedagogical resources able to afford the school learning with opportunities for revealing to learners the ongoing dance between intellect and emotions that normal human activity and functioning entails (Goleman, 1996).

Theory and Practice. Situated anywhere between progressive and traditional perspectives over what counts for an educational horizon in the ongoing continental reform rhetoric, the approaches to arts in the curricula across European systems of mainstream education varies greatly. This diversity is making visible a variety of false dichotomies in planning and delivering the curriculum, with that of opposing theoretical and practical aspects of learning and learning outcomes fuelling ongoing debates in education.

This particular opposition has interesting historical explanations. On one hand, in the history of Western Europe education, the Industrial Revolution has brought to the fore of pedagogical attention the importance of connecting the outcomes of schooling to the requirements of the new forms of organizing economic activity, labour and production. At its best, schooling was supposed to aim at professionalizing young people, meaning preparing them in knowledge, conduct, attitudes and skills for the work life. That meant that what was deemed worthy of making the object of learning in school was to be decided against new criteria: knowledge and skills that serve in the best and most efficient way to placing young people in jobs. From this angle, arts were not only marginalized, but to the extent they were allowed in the curriculum, they were transformed in content and approach so that it helped prompting deductive, propositional, practical and pragmatic knowledge to the fore of school based learning.

On the other hand, the history of arts and art schools in Europe provides other explanatory routes for the emergence of this particular dichotomy. In Ancient Rome it was possible to separate between artes liberales - dedicated to cultivating the spirit of the free man - and artes mechanichae (iliberales, sordidae, lat.) - preoccupied with manual production of goods and exclusively performed by slaves. Music was always assimilated to artes liberales, whereas painting and sculpting were included in the artes mechanichae - and the status quo of this separation will preserve throughout the entire Middle Eve. With the emergence and rise of guilds of painters and sculptors promoting specific ways of production and commercialization of art works, as well as specific forms of training based on apprenticeship models and complete immersion of disciples in the life and work style of their masters (Heinich, 1993), it is created a context of practice where a new social and economic status appears within reach for both the visual artists and the visual arts. In order to rise to the status of artes liberales, the visual arts of painting and sculpting were subjected to an 
intensified intellectualization process in the course of the XVI-th and the beginning of the XVII-th century. About that time two academies of paining and sculpting have been documented to have been set up in Florence and, later, in France, promoting the study of philosophy, anatomy and mathematics along with the learning of drawing and sculpting (Darras, in Bresler, ed., 2007). The academies and the guilds have had a parallel functioning up until the XVIII-th century, when the guilds would disappear.

The visual arts have had a long and difficult history being confirmed among the artes liberales. Their long journey to affirmation has included stages of deep transformation and assumed intellectualization, the academies promoting a double pedagogical strategy: one designated to the reasoning and theory, the other to the hands and practice (Batteux, 1747, in Heinich, 1993, p.93). The echoes of these formative practices can be recognized in some of today's arts schools' ethos, restricting the legitimacy of manual, technical, practical learning in visual arts for the benefit of pedagogical approaches worthy of artes liberales, like the study of aesthetics, art theory, history of art etc.

In the mainstream curriculum, the tendencies to marginalize arts are explainable by this very ambivalence of arts education's advocates: should they voice an intellectualist approach, it follows that the pragmatic, job - related value of the knowledge they advocate for is reduced; should a more technical, manual approach to arts learning be advanced, the low intellectual status inherited from the age of artes liberals vs. artes mechanichae is brought to the fore of curriculum decision making. Either way, it may seem like a lost battle. Yet arguments in favour of sorting out this error in interpreting the curriculum have been put forth by a huge number of well-known educationalists: Johann Pestalozzi (1746 - 1848), Maria Montessori (1870 - 1952), Rudolf Steiner (1961 - 1925), Carl Orff (1895 - 1982), John Dewey (1859 - 1952), Lev Vygotsky (1896 -1934) and many others.

In overcoming the shortcomings of this false dichotomy, all the writers mentioned above propose placing the learner and the learning experience at the centre of our pedagogical thinking and curricular decision-making. By making the learner, the experience of learning and the learning action the priority in educational practice, the material and immaterial, theoretical and practical aspects of learning are engaged in a dynamic relationship to one another, shifting our focus from the dichotomy of theory and practice to finding what best serves enriching the learning experience and motivates participation to learning. To this avail, arts in all forms of expression may serve us well.

General versus specific aptitudes. The Eurydice Report (2009) is eloquently introducing empirical evidence of a great scope of aims which the arts education in Europe is directed at: in some approaches to curriculum, arts are credited to train and develop specific skills and competences, in others general, trans-curricular ones.

This diverse way of positioning toward educational goals has its' roots, yet again, in the cultural and historical tenets of the Industrial Revolution, in providing mass access to education, and in the rationalist view prompting 
quantification and cost-efficiency of investment in the social service of education by specializing formative routes and strictly correlating it to the requirements of the work market and material production. Specialization and early enrolment of students on educational routes fit for their intellectual potential were common attributes of post-war educational practice on both sides of the Atlantic, and continues to inform the educational practice in many countries today (Robinson, 2011). A key element in organizing education systems like that is the timely and proper diagnosis of the general and special aptitudes of the students, following a pedagogical logic placing with every subject a set of specific aptitudes for which the students need to prove initial appropriate potential. The human intelligence is considered a general potential, possible to appropriately diagnose by measurements of verbal, logic and mathematical intelligence. A special aptitude, named talent, is attributed to performing in the arts.

In contemporary cognitive psychology, the notion of talent is approached by researchers such as K. Anders Ericsson, or D.K. Simonton as a far more complex semantic reservoir. The talent functions as a "package, an ensemble" of characteristics acting simultaneously and harmoniously, much like the instruments in an orchestra (Kaufmann, apud. Stănciulescu, E., 2013). Talent may have genetic determinants; yet not the talent itself is inborn, as the genetic determinants for certain capacities and abilities, which may, at some point, form the nucleus of a talent (Coyle, 2009). Most forms of talent are, to a great extent, the result of social experiences and (self)education. Some are manifest early in childhood, others become manifest later during teenage, or even later in adult life. That is also because only in a social/ life context the "button" arousing the various characteristics of a person credited to harmoniously orchestrate a response to a situation and reveal noticeable performances can be activated. Also, talent is not just about technique (i.e. hearing, voice, sensing colour and forms, etc.), as it is about a number of volitional and motivational aspects as well (i.e. being particularly interested about a phenomenon, a capacity to selfmotivate, and self-discipline etc.) so far ignored in education (Stănciulescu, 2013).

Narrow educational pathways to specialization may have been a profitable strategy for common people decades or hundreds of years ago, when access to a profession may have constituted the springboard for an improved economic and social status because it was, to a greater extent than it is today, reasonable to expect that the parameters of life - professional or otherwise - may not change too much within the span of a lifetime. Today, "it is not possible, nor is it comfortable or profitable to set yourself - at any given age - on just one lane, however easy advancing on it may seem (or however much talent one may think he or she possesses, in order to perform in a certain area)" (idem). Talent needs a far more complex reading than it needed a few decades ago. Moreover, change has become so intrinsic to contemporary life, that it is simply not reasonable to think that any talent relevant for activity today will be necessary in the exact form and expression within the next few years (idem). 
Moving beyond this false dichotomy in arts education and in curriculum in general, comes as the reasonable thing to do. Disciplinary approaches to learning could be replaced by integrated and trans-disciplinary forms of structuring knowledge, for the simple reason that integrated approaches to learning afford the students opportunities to explore and uncover the myriad of possible combinations in which their characteristics, dispositions and abilities may become visible in their responses to the learning situations.

Individual versus collective perspective. We are used to think that creative labour is the manifestation of a solitary creative genius breaking through the confines of general conventions, progressing unabatedly towards creation and its' end products - i.e. a work of art, an original idea etc. - animated solely by one's will and personal qualities. Albeit history and collective memory is full of examples explicit of how we assimilate the work of art to the identity (name) of the creator (artist), this image of creative labour may prove deceiving. As Robinson put it, original ideas may spring out of the creative inspiration of the individual mind, but they never appear in a cultural void (2011, p.241).

In many national curricula the notion of creativity lacks a clear, operational definition and consideration; its' recognition is more implicit and determines a very diverse picture of approaches in the educational practice. In this diversity of approaches, one prominent dichotomy is that made explicit in how individual and collective planes intertwine in the anatomy of creative processes. On one hand, traditional approaches to school learning prompt an educational process structured on lessons, classrooms, standardized curriculum delivery and academic assessment, following the logic of accountability of learning outcomes and a cost-efficient view on investment in education. The pedagogical focus is on the direct relationship between the learners and the disciplinary contents being taught to them in the classroom, the memorization of which is later subjected to standardized testing.

On the other hand, the majority of proposed curricula - as the Eurydice Report shows - seem to associate creativity to specific areas of study and disciplines, namely those in the Arts curriculum. This is particularly challenging when it comes to assessing creativity (Craft, 2008) and to committing to a particular definition of the term creativity in the proposed approaches to school learning. Assimilating creativity to artistic creativity has almost a boomerang effect on the importance attributed to creativity and to arts in school cultures prioritizing records of quantifiable individual academic performances. Here arts and creativity will most likely be found at the margins of curriculum, less of an academic priority, more of a complementary, luxurious accessory to mainstream education. Moreover, it is very possible that in the course of transposition, creative processes available for teaching and learning in the classroom to bare very little similarities to the creative processes in the various art forms, out of the school.

Discussing the relationship between the perspectives of the individual and collective aspects of creativity is important for both forming a deeper understanding of the concept, and for locating possible continuities and 
discontinuities with the school culture and the approaches to creativity in the curriculum. The arguments put forth in this respect by the Organization for Economic Co-operation and Development - OECD (Lucas et al. 2013) seem worthy of attention. The OECD proposes a model of creativity based on five general dimensions: inquiry, perseverance, imagination, cooperation and discipline.

- Inquiry stimulates creative processes by focusing on the general disposition of seeking what is interesting, what stimulates, engages and may satisfy one's sense of wonder in the problem-spaces one engages with. This disposition prompts an interest for questioning what is relevant in the problem, to explore and investigate on multiple possible ways and challenge stereotypes and habitual manners of thinking about the problem, not taking anything for granted and engaging with a certain degree of scepticisms in taking things at their face value.

- Perseverance names the resilience, the tenacity in confronting adversities and difficulties, the courage to be different and take positive risks, a certain level of tolerance to uncertainty and being ready to see the road ahead, even when the aims are not yet clearly stated.

- Imagination stands for the ability to identify original solutions and possible courses of action, readiness to try, test and improve ideas, to make connexions, to analyze and structure in new ways separate elements and to be intuitive about new possible connexions and ideas.

- Collaboration, because creative processes are social and are collaborative in their nature (John-Steiner, 2006 apud. Lucas et al, 2013). This means to share the fruits of creativity, to offer and receive feed-back - which is an action catapulting the desire to go on, to listen and to contribute relevantly to the ideas of others, to be a part of other people creative labour, when participation is relevant and instrumental.

- Discipline is the counter-point of that state of dreaming, traditionally associated with creative work, particularly in the arts. Creative labour may include routine work (if only we consider the number of hours going into perfecting a dance choreography, or in music performance etc., before going on stage), technique and skilful structuring of the creative product. Being disciplined means to allow time and pay attention, effort and will for training new techniques and perfecting older ones, it means reflection and inquiry over one's own creative work and its' various parts and aspects, and it means informed decision-making and taking pride in one's work. Attention to details, diligence in correcting errors and will to see the final product working well, just as intended or better are also distinctive components of the discipline of creative people.

Should we look at things from this perspective planning the curriculum beyond the confines of the myth of individual creativity (i.e completely free and relying solely on inspiration) - well to popular with many educationalists today, many of whom are the arts teachers themselves - seem possible. In writing this argument I have departed from thinking that we have a better chance at 
foreseeing courses of possible action on our way to embodying educational reforms in the classrooms should we try to understand whatever lies ahead for better or worse - on our way to fulfilling new visions of education.

\section{Conclusions}

It is important that, in deciding what the way ahead may look like, when considering the great diversity of approaches to educational policy and practices in Europe, to strive for a deep understanding of specific differences and in making informed decisions. This is particularly challenging in educational cultures where change is habitually pressured in a top-down manner, without the exercise of inquiry, critical analysis and consensus building on an on-going, multi-voiced debate of possible courses of action and examples of best-practice. Whilst comparisons are often proposed, it is quite frequent that these comparisons are surfacing the deep cultural and historical tenets of various educational approaches, at the expense of rushing into not quite successful implants of practice from one system of education to another.

\section{Bibliography}

1. Bamford, A., Wimmer, M. (2012). The Role of Arts Education in Enhancing School Attractiveness: a literature review, European Expert Network on Culture (EENC) Paper, February.

2. Coyle, D. (2009). The Talent Code. New York: Random House, Inc.

3. Craft, A. (2008). Trusteeship, wisdom and the creative future of education?.UNESCO Observatory: Journal of Multi-Disciplinary Research in the Arts, 1(3), 1-20.

4. Darras, B. (2007). International commentary, France. In L. Bresler (ed.)International handbook of research in arts education. Dordrecht: Springer, pp. 31-34.

5. Eurydice (2009). Arts and Cultural Education at School in Europe, Brussels: EACEA.

6. Gardner, H. (1993). Frames of Mind: The Theory of Multiple Intelligences, Fontana, Londra.

7. Goleman, G. (1996). Emotional Intelligence, Bloomsbury, Londra.

8. Heinich, N. (1993). Du peintre à l'artiste. Artisans et académiciens à l'âge classique. Paris: Les Editions de minuit, p. 244.

9. Kaufmann, S.B. (2013) What is talent - and can science spot what we will be best at?, https://www.theguardian.com/science/2013/jul/07/can-science-spot-talentkaufman.

10. Lucas, B., Claxton, G., Spencer, E. (2013). Progression in Student Creativity in School: First Steps Towards New Forms of Formative Assessments, OECD Education Working Papers, No. 86, OECD Publishing.

11. Robinson, K. (2011). O lume ieșită din minți. Revoluția creativă a educației. Ediție revizuită și actualizată, Editura Publica, București.

12. Stănciulescu, E. (2013). Descoperă-ți talentul și urmează-l...așa să fie oare?, http://elisabetastanciulescu.ro/2013/08/coaching-style-descopera-talentul-si-urmeaza-1asa-sa-fie-oare/. 